\title{
PENGARUH BELANJA MODAL TERHADAP KESEJAHTERAAN MASYARAKAT
}

\author{
Endy Grade Tampubolon
}

\author{
Program Studi Pendidikan Ekonomi
}

Fakultas Ilmu Pendidikan dan Pengetahuan Sosial, Universitas Indraprasta PGRI Jakarta Email: endygrade.tampubolon@unindra.ac.id

Diterima: Februari; Disetujui: Maret; dipublikasikan: 28 April 2019

\begin{abstract}
This study aims to look at the effect of capital expenditure on the economic growth of districts/cities in Indonesia during the period 2014 to 2017 and see the impact of economic growth on community welfare which is proxied by the human development index number. Using the WarpPLS adopting a purposive sampling method, testing was carried out for 415 autonomous districts and 93 autonomous cities in Indonesia using data series 2014-2017. The results of this study indicate that capital expenditure has a positive effect on economic growth. Furthermore, economic growth has been proven to improve the welfare of the community.
\end{abstract}

Keywords: Capital Expenditures, Economic Growth, Community Welfare

\begin{abstract}
ABSTRAK
Penelitian ini bertujuan untuk melihat pengaruh belanja modal terhadap pertumbuhan ekonomi kabupaten/kota di Indonesia selama periode 2014 sampai dengan 2017 serta melihat dampak pertumbuhan ekonomi terhadap kesejahteraan masyarakat yang diproksikan oleh angka indeks pembangunan manusia. Dengan menggunakan WarpPLS mengadopsi purposive sampling method, pengujian dilakukan untuk 415 kabupaten otonom dan 93 kota otonom di Indonesia dengan menggunakan data seri 2014-2017. Hasil dari penelitian ini menunjukkan bahwa belanja modal berpengaruh positif terhadap pertumbuhan ekonomi. Selanjutnya pertumbuhan ekonomi terbukti telah meningkatkan kesejahteraan masyarakat.
\end{abstract}

Kata kunci: Belanja Modal, Pertumbuhan Ekonomi, Kesejahteraan Masyarakat 


\section{PENDAHULUAN}

Beberapa tahun belakangan ini pemerintah Indonesia terlihat sangat serius bahkan memprioritaskan pembangunan infrastruktur di seluruh wilayah Indonesia. Dengan pembangunan infrastruktur ini akan terjadi pemerataan di tiap-tiap daerah, meningkatkan daya saing tiap daerah, sekaligus mengurangi disparitas antardaerah. Infrastruktur yang diprioritaskan dalam pembangunan ini adalah konektivitas antardaerah, seperti pembangunan jalan tol, pembangunan dan/atau perbaikan bandar udara, pembangunan dan/atau perbaikan terminal penumpang. Untuk mendukung pertanian, prioritas lain yang dilakukan pemerintah adalah membenahi irigasi dengan membangun bendungan-bendungan, sehingga kebutuhan irigasi dapat terpenuhi. Selain konektivitas dan irigasi, pemerintah juga membuat program satu juta rumah.

Sebagai contoh, kondisi infrastruktur di Papua selama ini belum mampu memenuhi kebutuhan masyarakat. Terbatasnya konektivitas antardaerah di Papua atau antarpulau dari Papua maupun menuju Papua menyebabkan pelaku bisnis berkeberatan untuk melakukan investasi di daerah ini. Kondisi inilah yang menghambat pertumbuhan ekonomi di Papua.

Contoh lain ditemukan di kota Cirebon. Pembangunan jalan tol Cikopo-Palimanan (Cipali) merangsang pertumbuhan ekonomi di kota tersebut dengan bertambahnya jumlah hotelhotel yang baru dibangun. Dampak lain dari pembangunan infrastruktur ini terlihat di provinsi Banten khususnya pada sektor industri. Terjadi peningkatan yang signifikan pada triwulan III tahun 2015 menjadi 3,44 persen. Angka ini lebih besar dari triwulan II 2015 yang hanya mencapai 2,58 persen.

Peningkatan yang signifikan ini merupakan dampak naiknya permintaan pada industri logam dasar atau baja dalam negeri. Sebelumnya permintaan pada industri logam dasar atau baja di dalam negeri sempat menurun karena meningkatnya permintaan atas baja impor. Upaya pemerintah menghimbau para pelaksana projek agar menggunakan baja dalam negeri dalam rangka pembangunan projek infrastruktur telah mendorong meningkatnya indeks produksi baja.

Presiden Indonesia menyebutkan pembangunan infrastruktur ini dapat mempercepat pemerataan ekonomi. Oleh karena itu, presiden menginstruksikan agar anggaran dana desa ditambah program kementerian yang dikucurkan ke daerah-daerah dapat dimanfaatkan dengan model padat karya, sehingga menciptakan lapangan pekerjaan dan menyerap tenaga kerja sebanyak-banyaknya di daerah.

Rodrigo Chaves, Kepala Perwakilan Bank Dunia untuk Indonesia pada situs resmi Kementrian Keuangan Republik Indonesia juga berpendapat yang sama dengan presiden yang mengatakan bahwa pembangunan infrastruktur yang berkesinambungan untuk penyediaan transportasi umum di daerah-daerah yang belum terhubung, air bersih untuk kebutuhan masyarakat, perumahan masyarakat yang terjangkau, serta fasilitas-fasilitas sanitasi dapat mempercepat pertumbuhan ekonomi dan mengangkat jutaan masyarakat Indonesia keluar dari kemiskinan yang dialami.

Untuk merealisasikan program pemerintah dalam bidang pembangunan seperti ini, pemerintah menganggarkan belanja secara rutin. Anggaran belanja pemerintah untuk pembangunan ini disebut dengan belanja modal. Realisasi total belanja modal untuk kabupaten/kota se-Indonesia yang dianggarkan pemerintah dari 2010 hingga 2013 menunjukkan peningkatan. Pada 2011 total belanja modal naik sebesar 16,86\% dari tahun sebelumnya, pada 2012 naik sebesar 23.04\% dari 2011, dan pada 2013 naik sebesar 25,79\% dibanding 2012 seperti yang ditunjukkan pada tabel di bawah ini. Dengan bertambah besar anggaran yang terealisasi, diharapkan meningkatkan kesejahteraan masyarakat. 
Tabel 1 - Persentase Kenaikan Belanja Modal

\begin{tabular}{ccc}
\hline Tahun & $\begin{array}{c}\text { Realisasi Belanja Modal } \\
\text { (dalam ribuan rupiah) }\end{array}$ & $\begin{array}{c}\text { Persentase Kenaikan } \\
\text { Belanja Modal }\end{array}$ \\
\hline 2010 & 140.218 .082 .759 & \\
2011 & 163.800 .422 .746 & $16,82 \%$ \\
2012 & 201.630 .595 .263 & $23,10 \%$ \\
2013 & 253.598 .459 .240 & $25,77 \%$ \\
\hline
\end{tabular}

sumber: www.bps.go.id

Dari data yang dipublikasikan oleh Badan Pusat Statistik ditemukan selain peningkatan belanja modal, kesejahteraan masyarakat juga meningkat. Pada 2010 tingkat kesejahteraan masyarakat Indonesia secara keseluruhan yang diproksi oleh Indeks Pembangunan Manusia (IPM) berada pada angka 72,27 dan mengalami kenaikan pada 2011 menjadi 72,77, 2012 berada pada angka 73,29 dan di 2013 berada pada angka 73,81.

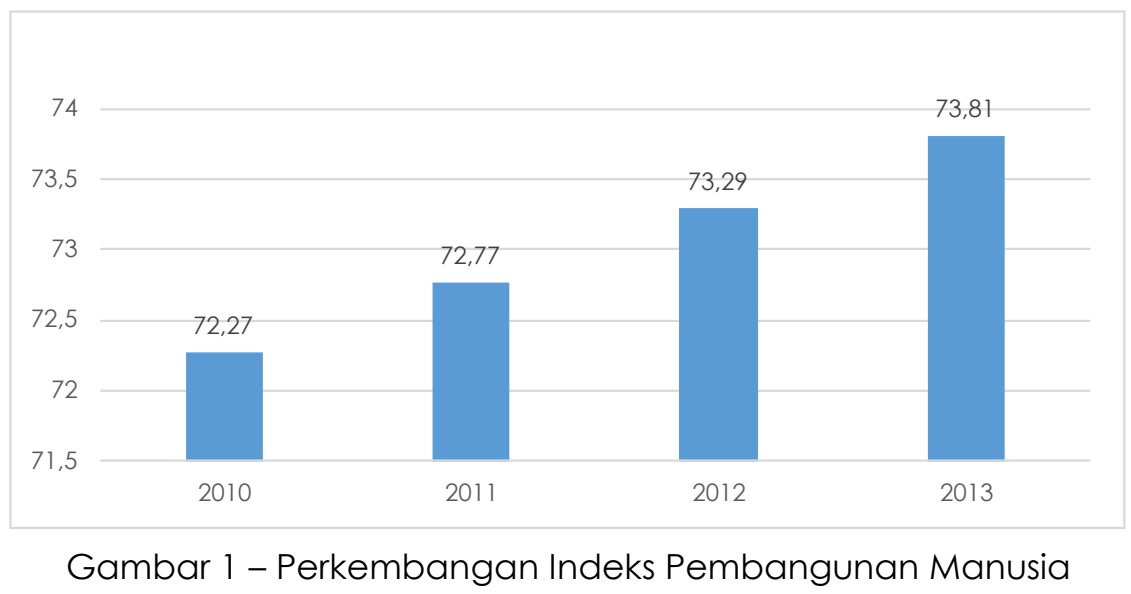

Jika dilihat data belanja modal dan angka indeks IPM sama-sama mengalami peningkatan pada periode tahun yang sama. Sebagai kesimpulan awal dapat dinyatakan bahwa peningkatan belanja modal akan berdampak pada peningkatan kesejahteraan masyarakat. Namun, beberapa media berpendapat bahwa pembangungan infrastruktur justru memiskinkan rakyat, seperti yang disebutkan Asfinawati, ketua Yayasan Lembaga Bantuan Hukum Indonesia (YLBHI) pada laman www.benarnews.org. Menurutnya sejumlah masyarakat terusir dan kehilangan aset dari lokasi yang terkena pengerjaan projek pembangunan infrastruktur tersebut.Aset yang hilang tidak hanya yang berwujud, seperti rumah, tanah, dan harta benda lainnya, tetapi juga aset yang tidak berwujud, seperti pelanggan tetap dari warung atau toko yang telah lama beroperasi di lokasi tersebut. Ketika warung atau toko tersebut membuka usaha di lokasi yang baru, artinya mereka merintis dari awal lagi. Beberapa penelitian mengkaji dampak belanja pemerintah terhadap kesejahteraan masyarakat menunjukkan pengaruh yang negatif. Artinya, peningkatan belanja pemerintah justru tidak meningkatkan kesejahteraan masyarakat.

Menurut Mitchell (2005) meningkatnya belanja pemerintah tidak serta merta meningkatkan kesejahteraan masyarakat Amerika. Hal ini disebabkan oleh pengalokasian belanja yang tidak tepat bahkan menjadi pemborosan. Hasil penelitian Ighodaro \& Oriakhi (2010) menunjukkan bahwa teori Wagner yang mengatakan bahwa pertumbuhan ekonomi industri akan diikuti oleh peningkatan gross national product melalui belanja pemerintah, tidak berlaku. Okoro (2013) menemukan dari 1980 sampai dengan 2011 belanja pemerintah selalu meningkat. Namun tidak memberikan dampak positif terhadap kesejahteraan masyarakat, bahkan Nigeria tercatat dalam kategori negara termiskin di dunia. Iheanacho (2016) juga 
menunjukkan belanja pemerintah berdampak negatif terhadap kesejahteraan masyarakat di Nigeria. Hal ini disebabkan oleh belanja pemerintah lebih banyak dialokasikan untuk kegiatan militer daripada kegiatan ekonomi.

Setiap individu menginginkan hidup yang sejahtera. Dalam Kamus Besar Bahasa Indonesia, sejahtera berarti aman, sentosa dan makmur. Ini berarti bahwa setiap individu menginginkan suatu keadaan yang terbebas dari segala bentuk ancaman atau gangguan yang memengaruhi kemampuan terpenuhinya kebutuhan hidupnya. Kebutuhan hidup individu mencakup dapat membaca, makan, dan memberikan hak suara (Sen dalam Pressman, 2006:287289)

Pemerintah memegang peranan penting dalam mewujudkan cita-cita individu warga negaranya, yaitu kesejahteraan. Bahkan dalam UUD 1945 pasal 33 ayat 2 telah tercantum bahwa negara diberi kewenangan penuh untuk mengelola cabang-cabang produksi yang penting bagi negara dan menguasai hajat hidup orang banyak. Selanjutnya pada pasal 33 ayat 3 UUD 1945 menegaskan bahwa penguasaan ini ditujukan untuk kemakmuran rakyat. Oleh karena itu, pemerintah harus mengalokasikan sebagian dananya dalam bentuk belanja modal untuk kegiatan yang meningkatkan kesejahteraan rakyat.

Ekonom Rostow \& Musgrave menjelaskan hubungan perkembangan pengeluaran pemerintah terhadap pembangunan ekonomi dengan membaginya dalam tahap awal, tahap menengah dan tahap lanjut. Pada tahap awal perkembangan ekonomi, presentase pengeluaran pemerintah sangat besar karena pemerintah harus menyediakan fasilitas dan pelayanan, seperti pendidikan, kesehatan, transportasi. Kemudian pada tahap menengah pembangunan ekonomi, pengeluaran pemerintah masih diperlukan untuk meningkatkan pertumbuhan ekonomi. Pada tingkat lanjut, Rostow menjelaskan bahwa aktivitas pemerintah beralih dari penyediaan prasarana ke pengeluaran-pengeluaran untuk aktivitas social, seperti kesejahteraan hari tua, program pelayanan kesehatan masyarakat.

Adolf Wagner memperkenalkan hukum pengeluaran pemerintah yang semakin meningkat yang menunjukkan bahwa pengeluaran pemerintah akan semakin meningkat seiring meningkatnya kegiatan pemerintah. Wagner menyatakan bahwa apabila pendapatan perkapita meningkat maka secara relatif pengeluaran pemerintah pun akan meningkat. Hal ini disebabkan oleh meningkatnya fungsi pertahanan keamanan dan ketertiban, meningkatnya fungsi kesejahteraan, dan meningkatnya fungsi pembangunan.

Pengeluaran pemerintah yang dialokasikan dalam belanja modal disesuaikan dengan kebutuhan sarana dan prasarana yang akan menunjang pelaksanaan program kerja pemerintah ataupun untuk fasiltas publik. Dengan meningkatnya dana belanja modal, diharapkan akan merangsang peningkatan kegiatan produksi sehingga memicu peningkatan pertumbuhan ekonomi. Penelitian Sularso \& Restianto (2011) membuktikan bahwa alokasi belanja modal berpengaruh positifterhadap pertumbuhan ekonomi. Ini artinya bahwa anggaran yang dialokasikan dapat merangsang terhadap perekonomian.

Menurut Halim (2008:4-5), belanja modal adalah investasi berupa pengadaan/pembelian aset yang bermanfaat lebih dari dua belas bulan untuk digunakan dalam kegiatan pemerintah yang bermanfaat secara ekonomis, social, sehingga dapat meningkatkan pelayanan pemerintah kepada masyarakat. Dengan demikian, belanja modal dapat meningkatkan kesejahteraan masyarakat.

Dalam Peraturan Menteri Keuangan Nomor 101/PMK. 02/2011 tentang Klasifikasi Anggaran, Lampiran III, Klasifikasi Jenis Belanja, belanja modal dipergunakan untuk antara lain:

1. Belanja modal tanah, yaitu seluruh pengeluaran untuk pengadaan/pembelian/pembebasan/penyelesaian, balik nama, pengosongan, penimbunan, perataan, pematangan tanah, pembuatan sertifikat tanah serta pengeluaran-pengeluaran lain 
yang bersifat administratif sehubungan dengan perolehan hak dan kewajiban atas tanah pada saat pembebasan/pembayaran ganti rugi sampai tanah tersebut siap digunakan/dipakai.

2. Belanja modal peralatan dan mesin, yaitu pengeluaran untuk pengadaan peralatan dan mesin yang digunakan dalam pelaksanaan kegiatan, antara lain biaya pembelian, biaya pengangkutan, biaya instalasi, serta biaya langsung lainnya untuk memperoleh dan mempersiapkan sampai peralatan dan mesin tersebut siap digunakan.

3. Belanja modal gedung dan bangunan, yaitu pengeluaran untuk memperoleh gedung dan bangunan secara kontraktual sampai dengan gedung dan bangunan siap digunakan meliputi biaya pembelian atau biaya konstruksi, termasuk biaya pengurusan IMB, notaris, dan pajak (kontraktual). Dalam belanja ini termasuk biaya untuk perencanaan dan pengawasan yang terkait dengan perolehan gedung dan bangunan.

4. Belanja modal jalan, irigasi, dan jaringan, yaitu pengeluaran untuk memperoleh jalan dan jembatan, irigasi dan jaringan sampai siap pakai meliputi biaya perolehan atau biaya kontruksi dan biaya-biaya lain yang dikeluarkan sampai jalan dan jembatan, irigasi dan jaringan tersebut siap pakai. Dalam belanja ini termasuk biaya untuk penambahan dan penggantian yang meningkatkan masa manfaat, menambah nilai aset, dan di atas batas minimal nilai kapitalisasi jalan dan jembatan, irigasi, dan jaringan.

5. Belanja modal lainnya, yaitu pengeluaran yang diperlukan dalam kegiatan pembentukan modal untuk pengadaan/pembangunan belanja modal lainnya yang tidak dapat diklasifikasikan dalam perkiraan kriteria belanja modal Tanah, Peralatan dan Mesin, Gedung dan Bangunan, Jaringan (Jalan, Irigasi dan lain-lain). Termasuk dalam belanja modal ini kontrak sewa beli (leasehold), pengadaan/pembelian barang-barang kesenian (art pieces), barang-barang purbakala dan barang-barang untuk museum, serta hewan ternak, buku-buku dan jurnal ilmiah sepanjang tidak dimaksudkan untuk dijual dan diserahkan kepada masyarakat. Termasuk dalam belanja modal ini adalah belanja modal nonfisik yang besaran jumlah kuantitasnya dapat teridentifikasi dan terukur.

6. Belanja modal Badan Layanan Umum (BLU), yaitu pengeluaran untuk pengadaan/perolehan/pembelian aset yang dipergunakan dalam rangka penyelenggaraan operasional BLU.

Penelitian tentang pengaruh belanja modal terhadap pertumbuhan ekonomi telah banyak dilakukan. Beberapa penelitian menunjukkan hasil yang positif, seperti yang dilakukan oleh Nurmainah (2013), Al-Fawwaz (2015). Penelitian mereka menunjukkan hasil bahwa belanja pemerintah dan investasi swasta berpengaruh signinfikan dan positif terhadap pertumbuhan ekonomi. Bertolak belakang dengan penelitian yang dilakukan oleh Iheanacho (2016), Okoro (2013), Ighodaro \& Oriakhi (2010) yang menunjukkan hasil negatif.

Dampak negatif dari pembangunan infrastruktur ini juga dirasakan oleh sebagian masyarakat yang tinggal di sekitar lokasi pembangunan infrastruktur. Pembangunan tol Cipali contohnya, menyebabkan kota yang dilintasi tol ini, yaitu kota Brebes terasa menjadi seperti kota mati beberapa tahun terakhir ini. Banyak kegiatan ekonomi di kota Brebes bergantung pada pengunjung yang singgah atau melintas melewati kota ini. Namun dengan adanya jalan tol Cipali ini, banyak kendaraan yang memilih tidak memasuki jalan dalam kota sehingga perdagangan di kota ini menurun drastis yang mengganggu pertumbuhan ekonomi. Dari uraian di atas, dibentuklah hipotesis sebagai berikut:

\section{H1 : Belanja Modal berpengaruh positif terhadap Pertumbuhan Ekonomi.}

Kesejahteraan masyarakat dapat dicapai apabila pemerintah dan swasta bermitra dalam berbagai sektor secara berkesinambungan. Todaro \& Smith (2015:128) berpendapat bahwa tidak selamanya kesejahteraan masyarakat meningkat seiring dengan peningkatan pertumbuhan ekonomi. Itulah sebabnya ukuran kesejahteraan masyarakat yang diperkenalkan oleh United Nation Development Programme (UNDP) sejak 1990 menggunakan Human Develompment 
Index (HDI) atau Indeks Pembangunan Manusia (IPM) dan metode inilah yang diadopsi Badan Pusat Statistik (BPS) untuk mengukur tingkat kesejahteraan masyarakat. Dalam IPM terkandung tiga dimensi penting, yaitu: (a) umur panjang, (b) hidup sehat dan (c) standar hidup yang layak. Ketiga dimensi tersebut disimpulkan dalam sebuah rumus sebagai berikut:

1. Dimensi kesehatan

$$
I_{\text {kesehatan }}=\frac{A H H-A H H_{\text {minimum }}}{A H H_{\text {maksimum }}-A H H_{\text {minimum }}}
$$

I : Indeks

AHH: Angka Harapan Hidup

2. Dimensi Pendidikan

$$
\begin{aligned}
& I_{H L S}=\frac{H L S-H L S_{\text {minimum }}}{H L S_{\text {mahsimum }}-H L S_{\text {minimum }}} \\
& I_{R L S}=\frac{R L S-R L S_{\text {minimum }}}{R L S_{\text {maksimum }}-R L S_{\text {minimum }}} \\
& I_{\text {pendidikan }}=\frac{I_{H L S}-I_{R L S}}{2}
\end{aligned}
$$

I : Indeks

HLS : Harapan Lama Sekolah

RLS : Rata-rata Lama Sekolah

3. Dimensi Pengeluaran

$$
I_{\text {pengeluaran }}=\frac{\ln (\text { pengeluaran })-\ln \left(\text { pengeluaran }_{\text {minimum }}\right)}{\ln \left(\text { pengeluaran }_{\text {maksimum }}\right)-\ln \left(\text { pengeluaran }_{\text {minimum }}\right)}
$$

dan untuk menghitung IPM digunakan rumusan sebagai berikut:

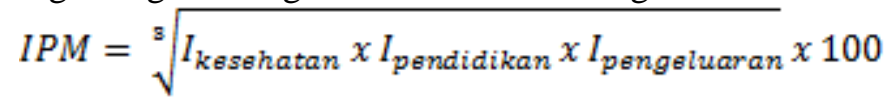

Adanya pertumbuhan ekonomi berarti ada peningkatan daya beli individu. Apabila daya beli indidviu meningkat, berarti terjadi peningkatan kemampuan individu untuk memenuhi kebutuhan standar hidupnya. Dari uraian tersebut dapat dibentuk hipotesis sebagai berikut:

\section{H2 : Pertumbuhan Ekonomi berpengaruh positif terhadap Kesejahteraan Masyarakat.}

Jika dirangkumkan dalam sebuah gambar, maka hipotesis yang dibangun dapat dilihat seperti berikut ini.

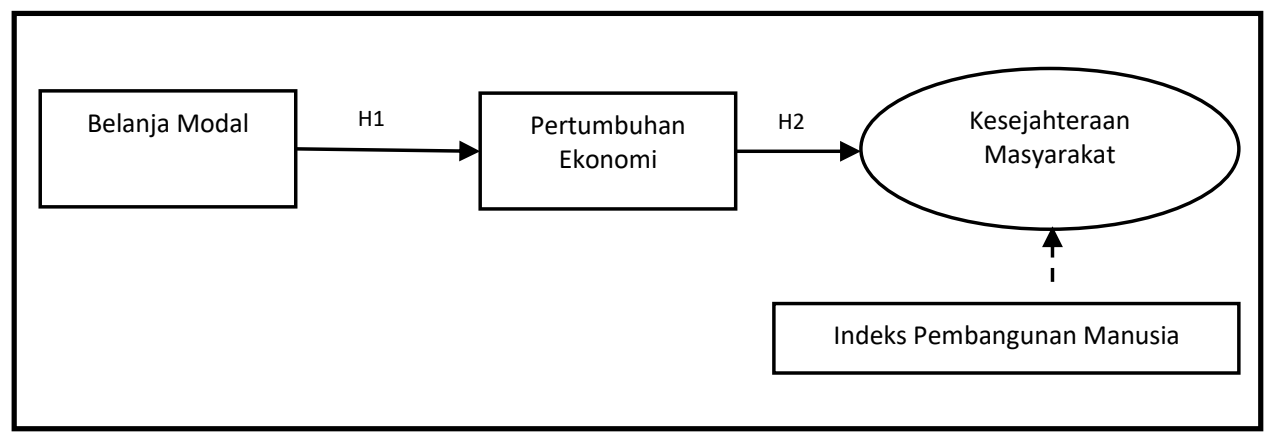

Gambar 2 - Kerangka Pengembangan Hipotesis 


\section{METODE}

Model penelitian ini adalah Structural Equation Model (SEM) dengan metode Partial Least Square (PLS) dan menggunakan alat analisis WarpPLS ver. 5.0.Pemilihan PLS-SEM dalam penelitian ini disebabkan oleh adanya variabel laten yang digunakan pada model yang dibangun. Selain itu, PLS-SEM tidak mensyaraktan data harus berdistribusi normal, dan dapat mengatasi semua jenis skala pengukuran baik interval, nominal, ordinal dan rasio, maupun mempermudah proses analisis data.

PLS dibentuk oleh dua persamaan, yaitu model struktural (structural model) atau sering disebut inner model dan model pengukuran (measurement model) atau sering disebutoutter model. Inner model menjelaskan hubungan antara konstrak yang satu dengan konstrak yang lainnya, sedangkan outer model menjelaskan hubungan antara konstrak dengan indikatorindikatornya. Konstrak itu sendiri pada PLS terbagi menjadi dua, yaitu konstrak eksogen dan konstrak endogen. Ghozali \& Latan (2014:14-19) menjelaskan dua variabel tersebut sebagai berikut:

1. Variabel eksogen adalah variabel yang memengaruhi atau menjadi penyebab dalam suatu model penelitian. Variabel eksgoen dalam penelitian ini adalah belanja modal $(\xi)$.

2. Variabel endogen adalah variabel yang dipengaruhi atau menjadi dampak dalam suatu model penelitian atau disebut juga sebagai variabel ganda karena dapat berfungsi sebagai variabel bebas, variabel terikat atau variabel intervening.

a. Variabel endogen intervening adalah variabel yang ikut berpengaruh saat variabel eksogen memengaruhi variabel endogen terikat. Variabel endogen intervening dalam penelitian ini adalah Pertumbuhan Ekonomi ( $\eta 1)$.

b. Variabel endogen terikat adalah variabel yang dipengaruhi oleh variabel eksogen maupun variabel endogen intervening. Variabel endogen terikat dalam penelitian ini adalah Kesejahteraan Masyarakat (n2).

Persamaan yang dibentuk pada penelitian ini adalah sebagai berikut:

Outer model $: x=\lambda 3 \eta 2$

Inner model $: \eta 1=\lambda 1 \xi 1$

$\eta 2=\lambda 2 \eta 1$

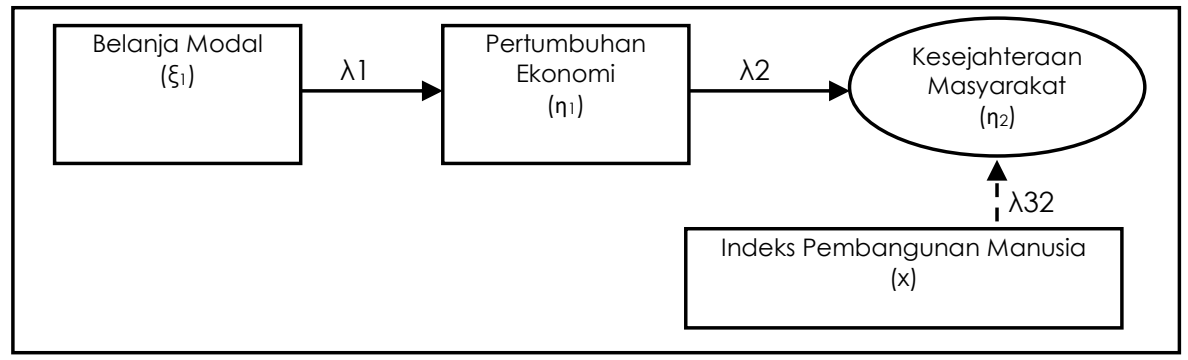

Gambar 3 - Diagram Jalur

Kriteria yang digunakan dalam pengambilan sampel pada penelitian ini adalah seluruh kabupaten/kota otonom di Indonesia yang menyediakan data belanja modal, produk domestik regional bruto dan indeks pembangunan manusia mulai dari 2014 sampai dengan 2017, kecuali untuk DKI Jakarta. Pengecualian tersebut dilakukan karena wilayah kota dan kabupaten di DKI Jakarta bukanlah daerah otonom. Oleh karena angka-angka yang digunakan cukup besar, sebelum melakukan pengolahan data, variabel belanja modal dan pertumbuhan ekonomi dilakukan konversi dengan logaritma natural (ln). 
Pada penelitian ini variabel-variabel yang digunakan diukur sebagai berikut. Belanja modal diambil dari angka realisasi belanja modal yang terdapat dalam laporan tahunan realisasi pengeluaran pemerintah kabupaten/kota yang dikeluarkan oleh Badan Pusat Statistik. Angka Produk Domestik Bruto (PDB) atas dasar harga konstan 2010 menjadi pengukuran untuk variabel Pertumbuhan Ekonomi. Indikator Kesejahteraan Masyarakat adalah Indeks Pembangunan Manusia yang diterbitkan oleh BPS.

\section{HASIL DAN PEMBAHASAN}

Untuk mengevaluasi model, model fit indices merupakan ukuran yang sangat penting karena menunjukkan kesesuaian model dengan data serta menunjukkan kualitas dari model yang diteliti.Hasil pengolahan data menunjukkan kriteriafit indicessebagai berikut:

Tabel 2 - Kriteria Pengujian Model

\begin{tabular}{|c|c|c|c|c|}
\hline Model Fit And Quality Indices & Indeks & p-value & Kriteria & Keterangan \\
\hline Average Path Coefficient (APC) & 0.580 & $\mathrm{P}<0.001$ & $\mathrm{P}<0,005$ & Diterima \\
\hline Average $R$-squared (ARS) & 0,337 & $\mathrm{P}<0.001$ & $\mathrm{P}<0,005$ & Diterima \\
\hline Average adjusted $R$-squared (AARS) & 0,337 & $\mathrm{P}<0.001$ & $\mathrm{P}<0,005$ & Diterima \\
\hline Average full collinearity VIF (AFVIF) & 1,747 & \multicolumn{2}{|c|}{$<=5$, ideally $<=3,3$} & Diterima \\
\hline Tenenhaus GoF (GoF) & 0.581 & \multicolumn{2}{|c|}{$\begin{array}{l}\text { small }>=0,1 ; \text { medium } \\
>=0,25 ; \text { large }>=0,36\end{array}$} & Diterima \\
\hline Sympson's paradox ratio $(S P R)$ & 1,000 & \multicolumn{2}{|c|}{$>=0,7$, ideally $=1$} & Diterima \\
\hline$R$-squared contribution ratio $(R S C R)$ & 1,000 & \multicolumn{2}{|c|}{$>=0.9$, ideally $=1$} & Diterima \\
\hline Statistical suppression ratio (SSR) & 1,000 & \multicolumn{2}{|c|}{ acceptable if $>=0.7$} & Diterima \\
\hline $\begin{array}{l}\text { Nonlinear bivariate causality direction } \\
\text { ratio }(N L B C D R)\end{array}$ & 1,000 & & Diterima \\
\hline
\end{tabular}

Dari tabel di atas, terlihat bahwa model yang digunakan dalam penelitian ini sudah memenuhi kritera-kriteria yang ditetapkan, sehingga model penelitian ini dapat digunakan untuk memprediksi pengaruh variabel eksogen terhadap variabel endogen.Untuk lebih jelasnya akan diuraikan sebagai berikut.

Konstruk model pengukuran atau outer model dalam penelitian ini berbentuk formatif, yaitu konstruk dijelaskan oleh indikator dan arah hubungannya yaitu dari indikator ke konstruk. Evaluasi outer model dilakukan dengan melihat signifikansi weight. Jika nilai weight yang dihasilkan signifikan (misalnya $\mathrm{P}<0,05$ ), maka indikator memenuhi kriteria indicator reliability. Selanjutnya karena konstruk formatif merupakan hubungan regresi berganda dari indikator ke konstrukm maka isu collinearity menjadi sangat penting untuk diperhatikan. Cara yang umum digunakan untuk menguji collinearity yaitu dengan melihat ukuran Variance Inflation Factor (VIF). Nilai yang dapat diterima untuk VIF adalah $<5$ namun beberapa literatur lain merekomendasikan nilai $\mathrm{VIF}<2,5$.

Dari pengujian weight dengan menggunakan WarpPLS didapati nilai $\mathrm{P}$ Value untuk indikator IPM adalah $<0,001$, sehingga indikator IPM memenuhi kriteria reliability. Pengujian collinearityyang ditunjukkan oleh nilai VIF adalah $<5$. Sehingga outer model ini bebas dari isu kolinearitas. Hasil pengujian pada weight dan collinearity ditunjukkan berikut ini.

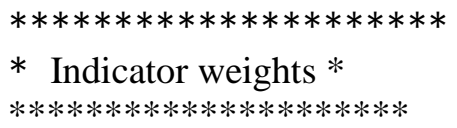




$\begin{array}{llllllllll} & \text { BelMod PertEko } & \text { KesMas } & \text { Type (a } & \text { SE } & \text { P value } & \text { VIF } & \text { WLS } & \text { ES } \\ \text { BM } & 1.000 & 0.000 & 0.000 & \text { Reflect } & 0.021 & <0.001 & 0.000 & 1 & 1.000 \\ \text { PE } & 0.000 & 1.000 & 0.000 & \text { Reflect } & 0.021 & <0.001 & 0.000 & 1 & 1.000 \\ \text { IPM } & 0.000 & 0.000 & 1.000 & \text { Formati } & 0.021 & <0.001 & 0.000 & 1 & 1.000\end{array}$

Notes: $\mathrm{P}$ values $<0.05$ and VIFs $<2.5$ are desirable for formative indicators; VIF $=$ indicator variance inflation factor;

WLS = indicator weight-loading sign $(-1=$ Simpson's paradox in l.v. $)$; ES = indicator effect size.

Dalam mengevaluasi inner model dengan PLS, dapat dilihat besarnya persentase variance yang dijelaskan oleh nilai Adjusted $\mathrm{R}^{2}$. Bila nilai Adjusted $\mathrm{R}^{2}$ adalah 0,70 disimpulkan bahwa model kuat, bila 0,45 disimpulkan model moderat dan bila 0,25 disimpulkan model lemah. Semakin besar nilai Adjusted $\mathrm{R}^{2}$, menujukkan bahwa prediktor model semakin baik menjelaskan variance. Dari hasil pengujian dengan WarpPLS didapati rata-rata nilai Adjusted $\mathrm{R}^{2}$ adalah 0,337 berarti model yang digunakan termasuk da;a, golongan moderat.

Sympson's paradox ratio (SPR) merupakan suatu ukuran indeks yang mengindikasikan masalah kausalitas. Idealnya indeks ini harus sama dengan 1 yang berarti tidak ada masalah Simpson's paradox dala sebuah model. Nilai SPR yang masih dapat diterima yaitu $\geq 0,07$ yang berarti $70 \%$ atau lebih dari path di dalam model bebas dari Simpson's paradox. Jika dilihat dari hasil pengujian WarpPLS pada tabel di atas, nilai SPR adalah 1, sehingga model yang digunakan bebas dari kausalitas.

Nilai GoF menunjukkan bagaimana kekuatan model memprediksi. Jika nilai GoF $<0,1$ berarti kekuatan prediksi model sangan lemah dan dipertimbangkan untuk diterima. Dari tabel hasil pengujian WarpPLS didapati nilai GoF adalah 0,58. Ini berarti kemampuan model untuk memprediksi sangat kuat.

Setelah model pengujian diterima, selanjutnya adalah pengujian hipotesis. Hasil yang diperoleh atas pengujian hipotesis pada penelitian ini dapat dilihat pada tabel berikut ini:

Tabel 3 - Hasil Pengujian Hipotesis

\begin{tabular}{llllll}
\hline Hipotesis & \multirow{2}{*}{ Prediksi } & $\begin{array}{l}\text { Hubungan } \\
\text { Variable }\end{array}$ & $\begin{array}{l}\text { Koefisien } \\
\text { Jalur }\end{array}$ & $\mathrm{p}$-value & Hasil \\
\hline $\mathrm{H} 1$ & Positif & $\mathrm{BM} \rightarrow \mathrm{PE}$ & 0,55 & $\mathrm{p}<0,01$ & Diterima \\
$\mathrm{H} 2$ & Positif & $\mathrm{PE} \rightarrow \mathrm{KM}$ & 0,61 & $\mathrm{p}<0,01$ & Diterima \\
\hline
\end{tabular}

Jalur pengujian hipotesis ditunjukkan pada gambar 4. Arah anak panah menunjukkan arah pengaruh, besaran koefisien dilambangkan oleh $\beta$, dan tingkat signifikansi yang ditunjukkan oleh $p$-value. Dari tabel 3 dapat diketahui bahwa dua hipotesis yang diuji, semuanya dapat diterima.

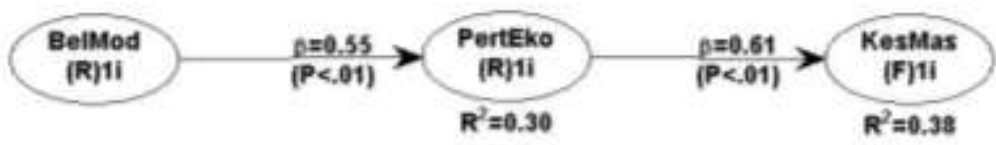

Gambar 4 - Output Pengujian Hipotesis

Peranan pemerintah dalam perekonomian disebutkan bersifat pro growth, yang artinya keterlibatan pemerintah dapat merangsang pertumbuhan ekonomi suatu negara. Dalam ekonomi makro juga disebutkan bahwa belanja pemerintah dapat meningkatkan output. Pembangunan 
yang dilakukan oleh pemerintah di hampir seluruh wilayah Indonesia telah meningkatkan pretumbuhan ekonomi. Pembukaan akses ke Papua contohnya, memberikan kemudahan jalur logistik yang selama ini sangat tersendat. Sama halnya dengan pembangunan jalur tol CikopoPalimanan, telah berhasil menyingkatkan waktu tempuh Jakarta-Semarang yang tadinya berkisar antara 25 jam, kini menjadi berkisar 5 jam 51 menit. Penelitian terdahulu juga banyak yang menunjukkan bahwa belanja modal berpengaruh positif terhadap pertumbuhan ekonomi.

Hasil pengujian hipotesis pertama, yaitu belanja modal berpengaruh positif terhadap pertumbuhan ekonomi menunjukkan nilai yang signifikan dengan $\mathrm{P}$ Value $<0,01$, lebih kecil dari nilai $\mathrm{P}$ Value yang ditetapkan, yaitu $<0,05$. Koefisien jalur dari pengujian ini menampilkan nilai 0,55 bertanda positif. Maka hipotesis pertama dapat diterima. Artinya apabila terjadi peningkatan belanja pemerintah yang dialokasikan dalam belanja modal, pertumbuhan ekonomi juga akan meningkat.

Pembangunan yang direalisasikan akan memberi akses yang lancar terhadap kegiatan ekonomi. Kegiatan ekonomi yang pesat dapat meningkatkan pertumbuhan ekonomi. Selain itu, pembangunan ini juga akan membuka kesempatan kerja, yang akhirnya akan meningkatkan pendapatan masyarakat. Apabila pendapatan masyarakat meningkat, masyarakat cenderung meningkatkan kualitas hidupnya dengan membelanjakan pendapatannya untuk pemenuhan kebutuhan hidup dasar, yaitu kebutuhan akan kesehatan dan kebutuhan akan pendidikan. Dengan pemenuhan kebutuhan hidup dasar ini, masyarakat dapat meningkatkan kesejahteraan hidupnya.

Pengujian terhadap hipotesis kedua, yaitu pretumbuhan ekonomi berpengaruh positif terhadap kesejahteraan masyarakat menghasilkan nilai $\mathrm{P}$ Value yang signifikan, yaitu $<0,01$ lebih kecil dari nilai $\mathrm{P}$ Value yang ditetapkan, yaitu $<0,05$.dan nilai koefisien $\beta=$ 0,61 dengan slop positif. Artinya setiap peningkatan pertumbuhan ekonomi, akan diikuti dengan peningkatan kesejahteraan masyarakat.

\section{SIMPULAN DAN SARAN}

Berdasarkan hasil pengujian tentang pengaruh belanja modal terhadap kesejahteraan masyarakat melalui pertumbuhan ekonomi, dapat disimpulkan sebagai berikut: (1) Belanja modal berpengaruh positif terhadap pertumbuhan ekonomi. Artinya semakin besar belanja pemerintah yang dialokasikan pada belanja modal, akan meningkatkan pertumbuhan ekonomi. Sehingga hipotesis H1 diterima. (2) Pertumbuhan ekonomi juga berpengaruh positif terhadap kesejahteraan masyarakat. Artinya bahwa apabila terjadi pertumbuhan ekonomi, akan meningkatkan kesejahteraan masyarakat. Maka hipotesis $\mathrm{H} 2$ diterima.

Pada penelitian ini, peneliti sulit mengamati kualitas belanja modal, karena angka realisasi belanja modal hanya menggambarkan besaran belanja modal yang terealisasi, tidak menunjukkan kualitas belanja modal tersebut. Oleh karena itu, disarankan untuk penelitian berikutnya menambahkan indikator-indikator lainnya, seperti tingkat korupsi, temuan-temuan BPK per Kabupaten/Kota, dan indikator lainnya yang mampu menggambarkan kualitas belanja modal.

\section{DAFTAR RUJUKAN}

Al-Fawwaz, Torki M. (2015). The Impact of Government Expenditures on Economic Growth in Jordan (1980-2013), International Business Research, 9.(1).2016.

Badrudin, R. (2012). Ekonomika Otonomi Daerah Ed. 1. Yogyakarta: Unit Penerbit dan Percetakan STIM YKPN. 
Ghozali, I \& Latan, H. (2014). Partial Least Squares: Konsep, Metode dan Aplikasi Menggunakan Program WarpPLS 4.0, Edisi 2, Semarang: Universitas Diponegoro.

Halim, A. (2007). Pengelolaan Keuangan Daerah, Edisi 2. Yogyakarta: UPP Sekolah Tinggi Ilmu Manajemen YKPN.

https://www.liputan6.com/bisnis/read/3608553/ini-deretan-infrastruktur-yang-dibangun-di-erajokowi, diakses pada 2 Nopember 2018, pkl. 12.37 WIB.

https://finance.detik.com/infrastruktur/d-3872627/jokowi-kejar-pemerataan-lewatpembangunan-infrastruktur, diakses pada 2 Nopember 2018, pkl. 12.37 WIB.

http://presidenri.go.id/berita-aktual/kunci-mensejahterakan-papua-fokus-dan-terkoordinasi.html, diakses pada 2 Nopember 2018, pkl 12.43 WIB.

Ighodaro, Clement.A.U. \& Oriakhi, D., E. (2010). Does The Relationship Between Government Expenditure And Economic Growth Follow Wagner's Law In Nigeria?. Annals of the University of Petroşani, Economics, 10(2), 2010, 185-198.

Iheanacho, E. (2016). The Contribution of Government Expenditure on Economic Growth of Nigeria Disaggregated Approach. International Journal of Economics \& Management Sciences.

Okoro, A. S. (2013). Government Spending and Economic Growth in Nigeria (1980-2011). Global Journal of Management and Business Research Economics and Commerce. Vol. 13 Issue 5 Version 1.0.

Pressman, S. (2006). Fifty Major Economists 2nd Ed., Oxon: Routledge.

Sularso, H. \& Restianto, Y.E. (2011). Pengaruh Kinerja Keuangan Terhadap Alokasi Belanja Modal dan Pertumbuhan Ekonomi Kabupaten/Kota di Jawa Tengah. Jurnal Media Riset Akuntansi, Vol. 1 No. 2:109-124.

Todaro, Michael P., \& Smith, Stephen C., (2011). Pembangunan Ekonomi Edisi Kesebelas Jilid 2, Jakarta: Penerbit Erlangga. , (2015). Economic Development 12th Edition, New York: Pearson.

Wator, Adrian Prama Arta Warat. (2013). Pengaruh Pengeluaran Pemerinah, Investasi Swasta Dan Tenaga Kerja Terhadap Pertumbuhan Ekonomi Di Indonesia, [Jurnal Ilmiah], Bogor, Fakultas Ekonomi Dan Manajemen, Departemen Ilmu Ekonomi, Institut Pertanian Bogor. 